\title{
Misuse of Methylphenidate and Attitudes About Methylphenidate Among Resident Physicians
}

\author{
Feridun Bulbul', Gokay Alpak', Ahmet Unal', Osman Hasan Tahsin Kilic², Berna Ermis², Haluk Asuman Savas ${ }^{3}$
}

ÖZET:

Uzmanlık eğitimi gören hekimlerin metilfenidatı uygunsuz kullanımı ve metilfenidata yaklaşımları

Amaç: Gençlerde Metilfenidat (MPH) hatalı kullanımı yüksek bulunmuştur. Bu suistimal genelde üniversitede okuyan öğrencilerde daha fazla bulunmaktadır. Bu çalışmada uzmanlık eğitimi gören doktorlar arasında MPH uygunsuz kullanım sıklığı ve uzmanlık eğitimi gören doktorların MPH hakkında bilgi düzeyleri araştırılmıştır.

Yöntem: Çalışmaya Gaziantep Üniversitesi Tıp Fakültesi Hastanesi'nde uzmanlık eğitimi gören tıp fakültesi mezunu 212 doktor alındı. 176 (\%83) kişi çalışmaya katılmayı kabul etti. Katılımcılara Ruh Sağlığı ve Hastalıkları Anabilim Dalı tarafından hazırlanan anket ve sosyodemografik veri formu verildi. Ankette katılımcilara 12 soru soruldu.

Bulgular: Katılımcıların 124 (\%70.5)'ü erkek 52 (\%29.5)'si kadındı. Katılımcıların ortalama yaşı 29.25 23.04 yıl (2444 yaş arası) idi. Katıımcıların 100 'ü dahili tıp bilimleri, 57 'si cerrahi tıp bilimleri, 19 'u temel tıp bilimlerinde uzmanlık eğitimi görüyorlardı. Katılımcıların 39 (\%22.2)'unda mesleki yaşamlarının MPH uygunsuz kullanımı saptandı. MPH uygunsuz kullanımı saptanan katılımcıların 19'u arkadaşönerisiyle, 20'si kendi kendine MPH başladığını belirtti. MPH kullanan katılımcıların 28 (\%15.9)'i tıpta uzmanlık sınavına (TUS) hazırlık döneminde kullandığını, 11 (\%6.25)'i ise TUS dönemi dışında MPH kullandıklarını belirtti. MPH kullanım sıkığı açısından erkekler (\%24.2)ve kadınlar (\%17.3) arasında fark saptanmadı $(p=0.32)$.

Tartışma: Bu çalışma uzmanlık eğitimi gören doktorlar arasında MPH uygunsuz kullanım sıklığının fazla olduğunu göstermektedir. Genelleme yapılabilmesi için çok merkezli çalışmalar gerekmektedir.

Anahtar sözcükler: metilfenidat, uygunsuz kullanım, hekimler

Klinik Psikofarmakoloji Bulteni 2014;24(2):135-8

\section{ABSTRACT:}

Misuse of methylphenidate and attitudes about methylphenidate among resident physicians

Objective: Misuse of methylphenidate (MPH) has been found to be highly prevalent in young individuals. MPH misuse is more frequent among college students. In the present study, we aimed to evaluate the frequency of misuse of MPH and knowledge level about this agent among resident physicians.

Method: A group of 212 resident physicians working in Gaziantep University Medical Faculty Hospital were enrolled in our study. Of this group, 176 (83\%) agreed to participate. Participants were asked to complete a twelve item questionnaire and a sociodemographic data sheet designed by the department of psychiatry.

Results: Of the participants, 124 (70.5\%) were male and 52 (29.5\%) were female. Mean age was $29.25 \pm 3.04$ (range: $24-44$ ) years. Of the participants, 100 were resident physicians in internal medicine, whereas 57 were in surgical specialties and 19 in basic sciences. It was found that 39 participants (22.2\%) had previously used $\mathrm{MPH}$ without a medical indication. Of the participants who reported misuse of $\mathrm{MPH}, 19$ participants indicated that they started using MPH by recommendation of their colleagues, whereas 20 participants indicated that they started using MPH by their own decision. Twenty eight participants (15.9\%) stated that they used MPH during the preparation period for the Medical Specialty Entrance Exam, while 11 participants (6.25\%) stated that they used MPH in a period unrelated to the Medical Specialty Entrance Exam. No significant difference was detected between male $(n=30 ; 24.2 \%)$ and female participants $(n=9 ;$ $17.3 \%$ ) regarding the frequency of misuse of $\mathrm{MPH}$.

Conclusion: This study shows that the frequency of misuse of MPH is high among resident physicians. Multi-centered studies are needed to generalize this conclusion.

Keywords: methylphenidate, misuse, physicians

Bulletin of Clinical Psychopharmacology 2014;24(2):135-8
'Assistant Professor, M.D., ${ }^{2}$ Psychiatrist, M.D., ${ }^{3}$ Professor of Psychiatry, M.D., Gaziantep University, School of Medicine, Department of Psychiatry, Gaziantep - Turkey

Address reprint requests to: Dr. Feridun Bulbul, Gaziantep University, School of Medicine, Department of Psychiatry, Gaziantep - Turkey

E-mail address:

frdnblbl@yahoo.com

Date of submission:

June 11, 2013

Date of acceptance: September 25, 2013

Declaration of interest:

F.B., G.A., A.U., O.H.T.K., B.E., H.A.S.: The authors reported no conflict of interest related to this article. 


\section{INTRODUCTION}

Methylphenidate is the most commonly chosen psychostimulant in the treatment of attention deficit and hyperactivity disorder. MPH has sympathomimetic and psychostimulant activities and it exerts its effects by blocking reuptake of catecholamines ${ }^{1}$. MPH exerts its central effects via dopamine rather than norepinephrine ${ }^{2}$. MPH increases energy and concentration level, improves school performance and reduces the need for sleep ${ }^{3}$. Improvement in attention by $\mathrm{MPH}$ is attributed to its effects leading to increase in dopamine release in the $\mathrm{CNS}^{4}$.

Misuse of methylphenidate (MPH) has been found to be highly prevalent in young individuals ${ }^{5}$. In a recent study from Iran, it has been shown that the MPH misuse was especially prevalent among college students ${ }^{5}$. It has a potential for abuse, although it has a wide safety margin ${ }^{6,7}$. It has been reported that the rate of use of prescribed stimulants varies between $5 \%$ and $35 \%$ among young adults of college age ${ }^{8}$. During the academic year, stressful periods including final exams can cause an increase in the popularity of stimulants such as $\mathrm{MPH}^{6,8}$.

In recent years, misuse of MPH has increased among medical students and other students ${ }^{5}$. Although there is no controlled study about MPH tolerance, clinicians and patients suggest that its effectiveness reduces over time and psychological addiction occurs ${ }^{5,9}$.

To the best of our knowledge, there is no study evaluating misuse of MPH and knowledge level about its effect among resident physicians. In the present study, the frequency of misuse of $\mathrm{MPH}$ among resident clinicians of Gaziantep University Medical Faculty Hospital during their professional life or education and their level of knowledge about MPH were investigated.

\section{METHODS}

Two hundred and twelve resident physicians working in Gaziantep University Medical Faculty Hospital were enrolled in our study. Of them, 176 (83.4\%) physicians accepted to participate. Seven physicians (3\%) were excluded from the study because they inappropriately filled out their questionnaire. Participants were asked to complete a twelve item pen and pencil questionnaire and a sociodemographic data sheet designed by the Psychiatry Department. All participants gave written informed consent. The questions asked were: 'Have you ever used methylphenidate before?', 'If you have used methylphenidate, who suggested it?', 'Did you use methylphenidate while preparing for the Medical Specialty Entrance Exam?', 'Have you ever suggested methylphenidate to somebody else?', 'Do you think methylphenidate has a potential for addiction?', 'Methylphenidate is a dangerous drug which needs to be used.', 'Provides increased concentration', 'Provides learning without rest', 'Decreases learning', 'It is used to decrease sleep', 'Its activity lasts for a few hours', 'Causes increased heart rate'. This study was approved by the Institutional Ethics Committee.

\section{Statistical Analysis}

Data were analyzed using the Statistical Package for the Social Sciences (SPSS) 18.0 version. Results were recorded as arithmetical mean \pm standard deviation and percentages. Categorical variables were analyzed by using chi-squared analysis or Fisher's exact tests. Numeric variables were analyzed using independent t-tests and one-way ANOVAs. The Kruskal-Wallis test was used for comparison of three groups.

\section{RESULTS}

Of the 212 subjects, 176 (83\%) resident physicians agreed to participate, while 29 (13\%) did not. Of the participants, 124 (70.5\%) were male and 52 (29.5\%) were female. The mean age was $29.25 \pm 3.04$ (range: 24-44) years. Of the participants, 100 were resident physicians in internal medicine, whereas 57 were in surgical specialties and 19 in basic sciences. Mean residency time was $25.95 \pm 13.55$ months.

It was found that 39 participants $(22.2 \%)$ had previously used MPH without a medical indication. Of the participants who reported misuse of MPH, 19 
Table 1: Level of knowledge about methylphenidate among participants $(n=176)$

\begin{tabular}{lccc} 
& Yes & No & Don't Know \\
\hline Provides increased concentration & $129(73.3 \%)$ & $7(4 \%)$ & $40(22.7 \%)$ \\
Provides learning without rest & $92(52.3 \%)$ & $27(15.3 \%)$ & $57(32.4 \%)$ \\
Decreases learning & $19(10.8 \%)$ & $104(59.1 \%)$ & $53(30.1 \%)$ \\
It is used to decrease sleep & $99(56.3 \%)$ & $34(19.3 \%)$ & $43(24.4 \%)$ \\
Its activity lasts for a few hours & $58(33 \%)$ & $46(26.1 \%)$ & $72(40.9 \%)$ \\
Causes increased heart rate & $103(58.5 \%)$ & $13(7.4 \%)$ & $60(34.1 \%)$
\end{tabular}

participants indicated that they started using MPH upon the recommendation of a colleague, whereas 20 participants indicated that they started using MPH by their own decision. Twenty-eight participants (15.9\%) cited that they used MPH during the preparation period for the Medical Specialty Entrance Exam, while 11 participants (6.25\%) cited that they used MPH at another time. Twenty-seven participants (15.3\%) reported that they had recommended MPH use to their colleagues. No significant difference was detected between male $(n=30 ; 24.2 \%)$ and female participants $(n=9$; $17.3 \%)$ regarding the frequency of misuse of $\mathrm{MPH}$ $(\mathrm{p}=0.32)$. One hundred and forty participants $(79.5 \%)$ stated that they knew of the addiction potential of $\mathrm{MPH}$. There were no differences between internal, surgical and basic medical sciences residents in terms of frequency of use of methylphenidate $(\mathrm{p}=0.29)$. Table 1 presents the level of knowledge about MPH among the participants.

\section{DISCUSSION}

To the best of our knowledge, this is the first study evaluating the frequency of misuse of MPH and knowledge level about MPH among resident physicians.

In our study, it was found that $22.2 \%$ of resident physicians had used MPH without a medical indication. In a study on Iranian medical students, MPH use was found to be $9 \%^{5}$. A wide range has been reported for MPH use in previous studies ${ }^{8,10}$. In a study on 2087 college students, Dupont et al. reported that $5.3 \%$ of the subjects used MPH at least once without a medical indication ${ }^{11}$. Interestingly, Low and Gendaszek reported prevalence of MPH or amphetamine illicit use as $35 \%$ among college students in a psychology class ${ }^{12}$.

We have found that $79.5 \%$ of the participants stated that they knew about the addiction potential of MPH. Despite this fact, the frequency of misuse of MPH of $22.2 \%$ in our study suggests that physicians used MPH knowledge of its addiction potential.

According to our results, $71.8 \%(n=22)$ of the participants, who had previously used MPH without a medical indication stated that they used MPH during the preparation period for the Medical Specialty Entrance Exam. In previous studies, students reported that they commonly used $\mathrm{MPH}$ during exam periods in order to understand or comprehend what they read, to stay awake, to enhance attention and to improve their academic success $^{3,10,13-15}$. Our finding that the physicians use MPH more frequently during exam periods is consistent with the literature.

In a study by Dupont et al., the majority of the students stated that they were supplied MPH by contacts, friend and relatives ${ }^{11}$. In our study, of the participants, who reported non-medical MPH use, $48.7 \%$ indicated that they started using MPH upon recommendation of a colleague, whereas $51.3 \%$ indicated that they started using MPH on their own. The self-decision of using drugs may be caused by the identity of being a physician and knowing the effects of MPH.

In previous studies, discrepant results were reported about rates of MPH use among genders ${ }^{16-18}$. In the Monitoring to Future Study, it was reported that MPH misuse within the prior year is more common among males than females ${ }^{19}$. In our study, no significant difference was found between males and females regarding frequency of misuse of MPH. This finding does not support the Monitoring to 


\section{Future Study.}

Among the questions about the knowledge of methylphenidate, we found $73.3 \%$ of the participants stated that methylphenidate provides increased concentration whereas in the study of Habibzadeh et al. among medical students, they reported the frequency of this knowledge as $50 \%^{5}$. The question 'MPH decreases learning?' revealed different results from their study ( $10.8 \%$ vs $31.3 \%$ stated yes). From another question, we found $52.3 \%$ of the participants stated that MPH provides learning without rest

\section{References:}

1. Ozcan IT, Toros F, Pekdemir H, Cicek D, Camsari S, Yurttas $\mathrm{M}$, et al. The effect of methylphenidate on time domain heart rate variability in the treatment of attention deficit and hyperactivity disorder. Çocuk ve Gençlik Ruh Sağllğı Dergisi 2004;11(3):117-22. (Turkish)

2. Rapport MD, Moffitt C. Attention deficit/hyperactivity disorder and methylphenidate. A review of height/weight, cardiovascular, and somatic complaint side effects. Clin Psychol Rev 2002;22(8):1107-31. [CrossRef]

3. Kadison R. Getting an edge--use of stimulants and antidepressants in college. N Engl J Med 2005;353(11):108991. [CrossRef]

4. Volkow ND, Fowler JS, Wang G, Ding Y, Gatley SJ. Mechanism of action of methylphenidate: insights from PET imaging studies. J Atten Disord 2002;(6 Suppl 1):S31-S43.

5. Habibzadeh A, Alizadeh M, Malek A, Maghbooli L, Shoja MM, Ghabili K. Illicit methylphenidate use among Iranian medical students: prevalence and knowledge. Drug Des Devel Ther 2011;3(5):71-6.

6. Kollins SH, MacDonald EK, Rush CR. Assessing the abuse potential of methylphenidate in nonhuman and human subjects: a review. Pharmacol Biochem Behav 2001;68(3):611-27. [CrossRef]

7. McCabe SE, Teter CJ, Boyd CJ, Guthrie SK. Prevalence and correlates of illicit methylphenidate use among $8^{\text {th }}, 10^{\text {th }}$, and $12^{\text {th }}$ grade students in the United States, 2001. J Adolesc Health 2004;35(6):501-4. [CrossRef]

8. Wilens TE, Adler LA, Adams J, Sqambati C Rotrosen J, Sawtelle $\mathrm{R}$, et al. Misuse and diversion of stimulants prescribed for ADHD: a systematic review of the literature. J Am Acad Child Adolesc Psychiatry 2008;47(1):21-31. [CrossRef]

9. Sallee FR, Gill HS. Neuropsychopharmacology III: psychostimulants. In Textbook of Pediatric Neuropsychiatry, Coffey CE, Brumbeck R, editors. Washington: American Psychiatric Press; 1998:1351-72.

10. DeSantis AD, Webb EM, Noar SM. Illicit use of prescription ADHD medications on a college campus: a multimethodological approach. J Am Coll Health 2008;57(3):315-24. [CrossRef] whereas they found $40.4 \%$. The question 'Its activity lasts for a few hours?' revealed similar results to their study.

The strength of this study is that it is the first study evaluating misuse of MPH among resident physicians. The limitation of this study is that it was performed exclusively on the resident physicians in Gaziantep University Medical Faculty Hospital. For comparison, similar studies need to be performed in other medical faculties and training and research hospitals that have residency programs.

11. Dupont RL, Coleman JJ, Bucher RH, Wilford BB. Characteristics and motives of college students who engage in nonmedical use of methylphenidate. Am J Addict 2008;17(3):167-71. [CrossRef]

12. Low KG, Gendaszek AE. Illicit use of psychostimulants among college students: a preliminary study. Psychol Health Med 2002;7(3):283-7. [CrossRef]

13. Ghanizadeh A. Knowledge of pharmacists regarding ritalin and ADHD and their attitude towards the use of ritalin to treat ADHD. Int J Clin Pharmacol Ther 2008;46(2):84-8. [CrossRef]

14. Ghanizadeh A, Zarei N. Are GPs adequately equipped with the knowledge for educating and counseling of families with ADHD children? BMC Fam Pract 2010;21:11-5. [CrossRef]

15. Teter CJ, McCabe SE, Cranford JA, Boyd CJ, Guthrie SK. Prevalence and motives for illicit use of prescription stimulants in an undergraduate student sample. J Am Coll Health 2005;53(6):253-62. [CrossRef]

16. Hall KM, Irwin MM, Bowman KA, Frankenberger W, Jewett DC. Illicit use of prescribed stimulant medication among college students. J Am Coll Health 2005;53(4):167-74. [CrossRef]

17. Simoni-Wastila L. The use of abusable prescription drugs: the role of gender. J Womens Health Gend Based Med 2000;9(3):289-7. [CrossRef]

18. Teter CJ, McCabe SE, Boyd CJ, Guthrie SK. Illicit methylphenidate use in an undergraduate student sample: prevalence and risk factors. Pharmacotherapy 2003;23(5):609-17. [CrossRef]

19. Johnston LD, O'Malley PM, Bachman JG, Schulenberg JE. Monitoring the Future National Survey Results on Drug use, 1975-2006: Volume II, College Students and Adults Ages 19-45. NIH Publication No. 07-6206. Bethesda, MD: National Institute on Drug Abuse; 2007:73-121. 